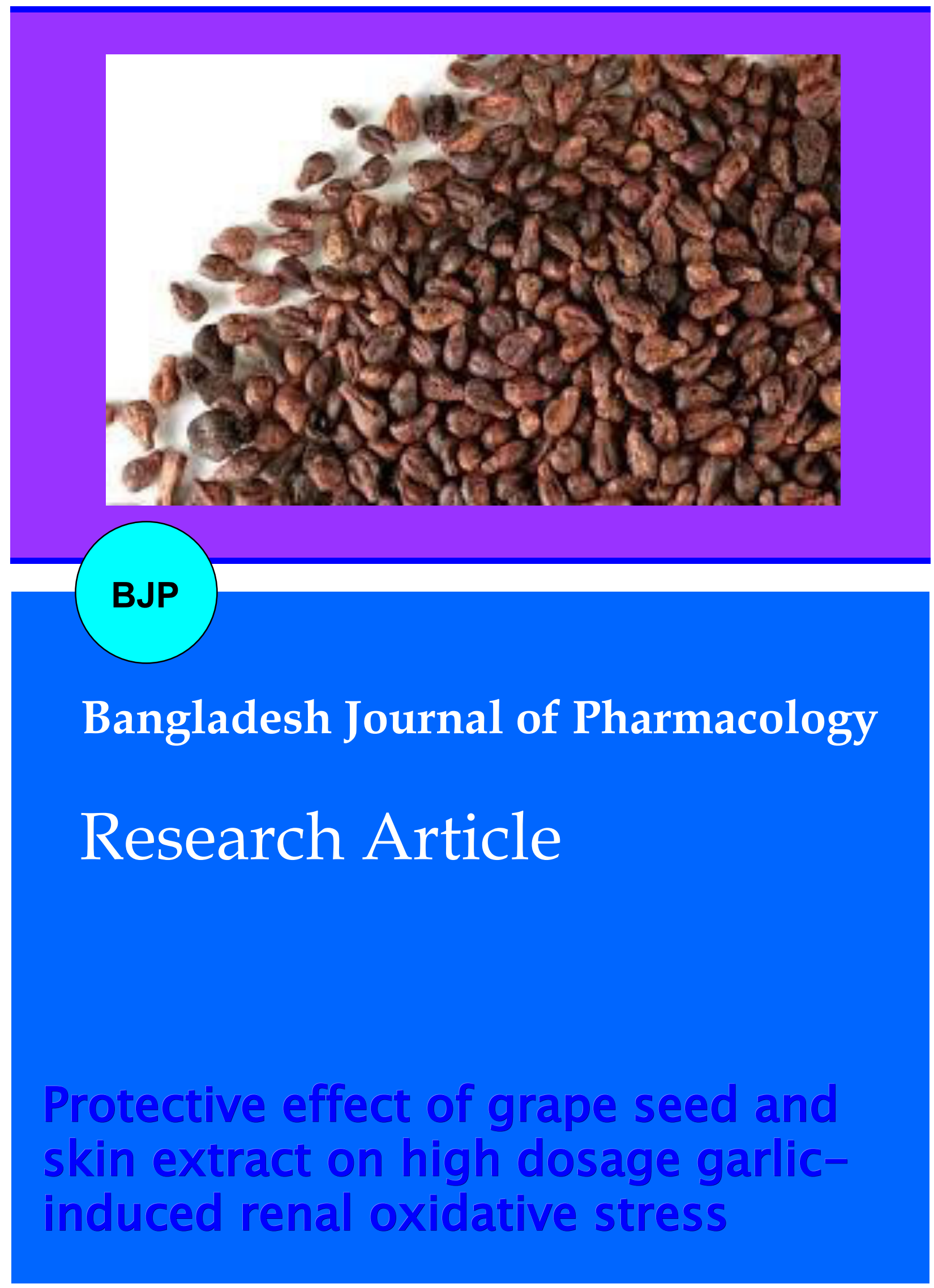


Abstracted/indexed in Academic Search Complete, Asia Journals Online, Bangladesh Journals Online, Biological Abstracts, BIOSIS Previews, CAB Abstracts, Current Abstracts, Directory of Open Access Journals, EMBASE/Excerpta Medica, Google Scholar, HINARI (WHO), International Pharmaceutical Abstracts, Open J-gate, Science Citation Index Expanded, SCOPUS and Social Sciences Citation Index;

ISSN: $1991-0088$

\section{Protective effect of grape seed and skin extract on high dosage garlic-induced renal oxidative stress}

\section{Sonia Hamlaoui', Oumayma Samti, Meherzia Mokni', Nadia Limam¹, Alice Carrier², Ferid Limam3, Mohamed Amri' ${ }^{1}$ Ezzedine Aouani3 and Lamjed Marzouki ${ }^{1}$}

${ }^{1}$ Laboratoire de Neurophysiologie Fonctionnelle et Pathologies, Département des Sciences Biologiques, Faculté des Sciences de Tunis, Campus Universitaire El Manar II-2092 Tunis, Tunisie; '2INSERM, U624 "Stress cellulaire», Case 915 Parc Scientifique de Luminy, 13288 Marseille Cedex 9, France; ' ${ }^{2}$ Laboratoire des Substances Bioactives, Centre de Biotechnologie, Technopole Borj-Cedria, BP-901, 2050 Hammam-Lif, Tunis, Tunisie.

\begin{tabular}{|c|}
\hline nfo \\
\hline $\begin{array}{lr}\text { Received: } & \text { 24 April } 2012 \\
\text { Accepted: } & \text { 22 May } 2012 \\
\text { Available Online: } & \text { 4 June } 2012 \\
\text { DOI: } 10.3329 \text { /bjp.v7i2.10482 }\end{array}$ \\
\hline $\begin{array}{l}\text { Cite this article: } \\
\text { Hamlaoui S, Samti O, Mokni M, } \\
\text { Limam L, Carrier A, Limam F, Amri } \\
\text { M, Aouani E, Marzouki L. Protective } \\
\text { effect of grape seed and skin extract } \\
\text { on high dosage garlic-induced renal } \\
\text { oxidative stress. Bangladesh J Phar- } \\
\text { macol. 2012; 7: 77-86. }\end{array}$ \\
\hline
\end{tabular}

\begin{abstract}
In this study, the protective role of grape seed and skin extract (GSSE) against high garlic dose-induced renal toxicity has been evaluated. Rats were intraperitoneally injected with garlic $(5 \mathrm{~g} / \mathrm{kg}$ bw) or GSSE $(500 \mathrm{mg} / \mathrm{kg} \mathrm{bw})$ or a combination of garlic and GSSE at the same doses daily for one month. Renal oxidative stress markers and anti-oxidant status were evaluated. We also measured plasma creatinine and urea. Data showed that high garlic dose induced renal toxicity by increasing creatinine and urea and a pro-oxidative status characterized by increased malondialdehyde, carbonyl protein, calcium and $\mathrm{H}_{2} \mathrm{O}_{2}$, but decreased free iron. Unexpectedly garlic increased catalase but decreased peroxidase and superoxide dismutase activities. GSSE co-treatment counteracted almost all garlic-induced deleterious effects. In conclusion, high garlic dose induced a pro-oxidative state characterized by the Fenton reaction between $\mathrm{H}_{2} \mathrm{O}_{2}$ and free iron, inducing $\mathrm{Ca}^{2+}$ depletion, while GSSE exerted anti -oxidant properties and $\mathrm{Ca}^{2+}$ repletion.
\end{abstract}

\section{Introduction}

Garlic (Allium sativum L.) has been widely used in traditional medicine and its health effects are mainly attributable to organosulfur compounds (Berginc et al., 2010) and to flavonoids and phenolics (Shirzad et al., 2011). However, some controversies persist concerning garlic dose and mode of administration. In a prior study, we showed that a high garlic dose administered intraperitoneally (ip) induced a pro-oxidant effect and ultimately blood toxicity (Hamlaoui-Gasmi et al., 2011a).

Grape seed and skin extract (GSSE) is a nutritional supplement exhibiting beneficial health effects (Suwannaphet et al., 2010) and containing polyphenolics classified as flavonoid and non-flavonoid compounds (Khanal et al., 2009). Flavonoids, which are highly concen- trated in seeds, are mainly composed of monomeric catechins, proanthocyanidins, and flavonols such as quercetin (Renaud and De Lorgeril, 1992). Nonflavonoids, highly abundant in skin, contain stilbenes such as resveratrol, which is at the basis of the French Paradox (Renaud and De Lorgeril, 1992). GSSE has wide ranging benefits as cardioprotective (Decordé et al., 2009) and neuroprotective effects (Wang et al., 2009). More specifically, resveratrol is multi-organ protective owing to its anti-oxidant (Kelen and Tepe, 2007) and anti-inflammatory properties (Kowalczyk et al., 2010). Proanthocyanidins exert antineoplasic effects by inducing cytotoxicity towards some cancer cells (Chatelain et al., 2011). Quercetin and rutin are neuroprotective (Jimenez-Aliaga et al., 2011), and catechin, epicatechin, and gallic acid exhibited cholesterol-lowering activity (Ngamukote et al., 2011). 
Table I

\begin{tabular}{|lcc|}
\hline \multicolumn{3}{|c|}{ Phenolics levels in carignan GSSE } \\
\hline Phenolics & Seed & Skin \\
\hline Total phenolics (mg/g extract) & 67 & 51 \\
Total flavonoïds (mg/g extract) & 16 & 14 \\
Non flavonoïds (mg/g extract) & 51 & 37 \\
Condensed tannins (mg/g extract) & 1.2 & 3.4 \\
Total anthocyanins ( $\mu \mathrm{g} / \mathrm{g}$ extract) & 0.99 & 0.96 \\
\hline
\end{tabular}

In the present paper, we characterized the effect of a high garlic dose when administered IP on renal oxidative stress as well as the protection offered by GSSE treatment. A high garlic dose induces a pro-oxidative state, and GSSE exerts potent anti-oxidative properties mainly by counteracting the Fenton reaction of $\mathrm{H}_{2} \mathrm{O}_{2}$ with free iron, leading to calcium disturbances.

\section{Materials and Methods}

\section{Reagents}

Thiobarbituric acid (TBA); 2,6,-di-tert-butyl-4- hydroxytoluene (BHT); trichloroacetic acid (TCA); hydrogen peroxide $\left(\mathrm{H}_{2} \mathrm{O}_{2}\right)$; 2-methoxyphenol (gaiacol); bovine catalase and 4-(1-hydroxy-2-methylamino-ethyl)-benzene-1,2-diol (epinephrine), 2,4,dinitrophenyl hydrazine (DNPH) were obtained from Sigma-Aldrich (Germany).

\section{Preparation of garlic and grape seed and skin extracts}

One kilogram of garlic (Allium sativum) was purchased from a local market, peeled, and ground for $30 \mathrm{~min}$ with an electric mincer (FP3121 Moulinex) until an aqueous suspension was obtained. It was diluted in double-distilled water at $4 \mathrm{~g} / \mathrm{mL}$ on the basis of the weight of the starting material and centrifuged (Beckman J20, $15 \mathrm{~min}$ at $10000 \times \mathrm{g}$ and $4^{\circ} \mathrm{C}$ ). The supernatant was aliquoted into $1 \mathrm{~mL}$ fractions and stored at $-80^{\circ} \mathrm{C}$ until use.

GSSE was processed from a grape cultivar (Carignan) of Vitis vinifera from northern Tunisia. Waste winemaking was collected from Tardi Cooperative Winery (Ain Ghelal). Seeds and skin were dried and ground separately with an electric mincer (FP3121 Moulinex) until a fine powder was obtained. Total phenolic content was determined by the folinCiocalteau colorimetric method (Singleton and Rossi, 1965), flavonoids and condensed tannins according to Dewanto et al. (2002) and Sun et al. (1998) respectively (Table I). Powder mixture containing grape seed (50\%) and skin $(50 \%)$ was dissolved in $1 \mathrm{~mL}$ of $10 \%$ ethanol in the dark, vigorously vortexed for $10 \mathrm{~min}$, centrifuged at $10,000 \mathrm{xg}$ for $15 \mathrm{~min}$ at $4^{\circ} \mathrm{C}$ for debris elimination and the supernatant containing soluble polyphenols was used.

\section{Animals and treatment}

Forty male Wistar rats (200-240 g) from Pasteur Institute of Tunis were used for these experiments in accordance with the local ethic committee of Tunis University, and care of animals which was in conformity with NIH recommendations (NIH, 1985). They were provided with food and water ad libitum and maintained in animal housing at a controlled temperature $\left(22 \pm 2^{\circ} \mathrm{C}\right)$ with a 12 hours light-dark cycle. Rats were divided into 4 groups of 10 animals each. Group I received ethanol 10\% (control), Group II aqueous extract of garlic $(5 \mathrm{~g} / \mathrm{kg} b w)$, Group III GSSE (500 mg/kg bw), and Group IV garlic plus GSSE. Animals were daily administered IP with one of these treatments for 30 days. Twenty-four hours after the last injection, animals were sacrificed, their kidneys rapidly excised, weighed and homogenized in phosphate-buffered saline $(\mathrm{pH} 7.4)$ with an ultrathurax T25 homogenisator at a $2 \mathrm{~mL} / \mathrm{g}$ ratio. After centrifugation at $10,000 \times \mathrm{g}$ for $10 \mathrm{~min}$ at $4^{\circ} \mathrm{C}$, supernatant was used for the determination of lipoperoxidation, carbonylation, anti-oxidant enzyme activities and intracellular mediators as free iron, ionizable calcium and $\mathrm{H}_{2} \mathrm{O}_{2}$. Blood was also collected, and the plasma was processed for creatinine and urea determination.

\section{Creatinine and urea measurement}

Whole blood was obtained by cardiac puncture and collected into heparinized tubes. Plasma was processed after centrifugation at $1,000 \times \mathrm{g}$ for $10 \mathrm{~min}$ at $4^{\circ} \mathrm{C}$ and creatinine and urea were determined using an auto blood analyser (Coulter).

\section{Lipoperoxidation determination}

Lipid peroxidation was assessed by MDA measurement according to the double heating method (Draper and Hadley, 1990). Briefly, aliquots $(200 \mu \mathrm{L})$ from kidney homogenates were mixed with $250 \mu \mathrm{L}$ BHT-TCA solution containing $1 \%$ BHT (m/v) dissolved in $20 \%$ TCA $(\mathrm{m} / \mathrm{v})$ and centrifuged at $1000 \mathrm{~g}$ for $5 \mathrm{~min}$ at $4^{\circ} \mathrm{C}$. The supernatant $(400 \mu \mathrm{L})$ was blended with $0.5 \mathrm{~N} \mathrm{HCl}$ $(80 \mu \mathrm{L})$, and $120 \mathrm{mM}$ TBA in $26 \mathrm{mM}$ Tris $(320 \mu \mathrm{L})$ and then heated at $80^{\circ} \mathrm{C}$ for $10 \mathrm{~min}$. After cooling, absorbance of the resulting pink chromophore was determined at $532 \mathrm{~nm}$ using a SmartSpec 3000 Bio-Rad UVvisible spectrophotometer (Germany). MDA levels were determined by using an extinction coefficient for the MDA-TBA complex of $1.56105 \mathrm{M}-1 \mathrm{~cm}-1$ (Draper and Hadley, 1990).

\section{Protein carbonylation}

Oxidative damage to proteins was evaluated by quantifying protein carbonylation in kidney homogenates according to Levine et al (1990). After proteins were 
precipitated with $20 \%$ TCA and centrifuged at $11,000 \times$ $\mathrm{g}$ for $3 \mathrm{~min}$ at $4^{\circ} \mathrm{C}$ (Beckman J20), the pellet was dissolved in $10 \mathrm{mM}$ DNPH-containing buffer. After 3 washes with ethanol-ethylacetate (1:1), the pellet was dissolved in $20 \mathrm{mM}$ potassium phosphate $(\mathrm{pH} 2.3)$ containing $6 \mathrm{M}$ guanidine $\mathrm{HCl}$, and absorbance measured at $366 \mathrm{~nm}$ using the molar extinction coefficient of $22,000 \mathrm{M}-1 \mathrm{~cm}-1$. Results were expressed as nmol carbonyl residues/mg protein.

\section{Protein determination}

Total soluble proteins were determined according to the biuret method (Ohnishi and Barr, 1978). Briefly, at acidic $\mathrm{pH}$, soluble proteins constituted with copper a colorful complex measurable at $546 \mathrm{~nm}$ using a SmartSpec 3000 BioRad UV-visible spectrophotometer.

\section{Anti-oxidant enzyme activity assays}

All spectrophotometric analyses of kidney anti-oxidant enzyme activities were performed with a SmartSpec 3000 Bio-Rad UV-visible spectrophotometer.

Catalase: CAT activity was assayed by measuring the initial rate of $\mathrm{H}_{2} \mathrm{O}_{2}$ disappearance at $240 \mathrm{~nm}$ (Aebi 1984). The reaction mixture contained $33 \mathrm{mM}(1000 \mu \mathrm{L})$ $\mathrm{H}_{2} \mathrm{O}_{2}$ in $50 \mathrm{mM}(1995 \mu \mathrm{L})$ phosphate buffer $(\mathrm{pH} 7.0)$ and $5 \mu \mathrm{L}$ of kidney extract. CAT activity was calculated using an extinction coefficient of $40 \mathrm{mM}-1 \mathrm{~cm}-1$ for $\mathrm{H}_{2} \mathrm{O}_{2}$ (Aebi 1984).

Peroxidase: POD activity was measured at $25^{\circ} \mathrm{C}$ using guaiacol as the hydrogen donor. The reaction mixture contained $9 \mathrm{mM}(25 \mu \mathrm{L})$ guaiacol, $19 \mathrm{mM}(100 \mu \mathrm{L}) \mathrm{H}_{2} \mathrm{O}_{2}$ in $50 \mathrm{mM}(870 \mu \mathrm{L})$ phosphate buffer $(\mathrm{pH} 7)$ and $5 \mu \mathrm{L}$ of kidney extract in a final volume of $1 \mathrm{~mL}$. The reaction was initiated by the addition of $\mathrm{H}_{2} \mathrm{O}_{2}$ and monitored by measuring the increase in absorbance at $470 \mathrm{~nm}$ every $30 \mathrm{sec}$ for $3 \mathrm{~min}$. POD activity was expressed as nmol of guaiacol oxidized per min and calculated using a molecular extinction coefficient of $26.2 \mathrm{mM}-1$ (Chance and Maehly, 1955).

Superoxide dismutase: SOD activity was determined by using a modified epinephrine assay (Misra and Fridovich 1972). At alkaline $\mathrm{pH}$, superoxide anion $\left(\mathrm{O}_{2^{-}}\right)$ causes the auto-oxidation of epinephrine to adrenochrome. One unit of SOD is defined as the amount of extract that inhibits the rate of adrenochrome formation by $50 \%$. Renal extract was added to a $2 \mathrm{~mL}$ reaction mixture containing $10 \mu \mathrm{L}$ bovine catalase $(0.4 \mathrm{U} / \mu \mathrm{L}), 20$ $\mu \mathrm{L}$ epinephrine $(5 \mathrm{mg} / \mathrm{mL})$, and $62.5 \mathrm{mM}$ sodium carbonate-sodium bicarbonate buffer ( $\mathrm{pH}$ 10.2). Changes in absorbance were recorded at $480 \mathrm{~nm}$. Characterization of SOD isoforms was performed using $\mathrm{KCN}$ (3 mM), which inhibites $\mathrm{Cu} / \mathrm{Zn}-\mathrm{SOD}$ or $\mathrm{H}_{2} \mathrm{O}_{2}(5 \mathrm{mM})$, affecting both $\mathrm{Cu} / \mathrm{Zn}-\mathrm{SOD}$ and Fe-SOD. Mn-SOD was insensitive to both inhibitors.

Free iron determination
Free iron was determined according to Leardi et al. (1998) using a commercially available kit from Biomaghreb (Ariana, Tunisia). Briefly, at acidic $\mathrm{pH} 4.8$ all $\mathrm{Fe}^{3+}$ released from transferrin was reduced by ascorbic acid into $\mathrm{Fe}^{2+}$, which constituted with ferrozine a purple colorful complex measurable at $560 \mathrm{~nm}$. Briefly, $50 \mu \mathrm{L}$ of renal extract was added to $250 \mu \mathrm{L}$ of reaction mixture containing ascorbic acid (5 g/L) and ferrozine (40 mM), and incubation was performed at $37^{\circ} \mathrm{C}$ for $10 \mathrm{~min}$.

\section{$\mathrm{H}_{2} \mathrm{O}_{2}$ determination}

$\mathrm{H}_{2} \mathrm{O}_{2}$ level was determined enzymatically according to Kakinuma et al. (1979) using a commercially available kit from Biomaghreb. Briefly in the presence of POD, $\mathrm{H}_{2} \mathrm{O}_{2}$ reacts with 4-amino-antipyrine and phenol to give a red-colored quinoeimine that absorbs at $505 \mathrm{~nm}$. Results are expressed as $\mathrm{mmol} \mathrm{H}_{2} \mathrm{O}_{2} / \mathrm{mg}$ protein.

\section{Calcium measurement}

Ionizable calcium was determined according to Stern and Lewis. (1957) using a commercially available kit from Biomaghreb. At basic $\mathrm{pH}$, calcium constitutes with cresolphtalein a purple colorful complex measurable at $570 \mathrm{~nm}$. Briefly, $50 \mu \mathrm{L}$ of kidney extract was added to $650 \mu \mathrm{L}$ of reaction mixture containing 2-amino-2-methyl 1-propanol buffer (500 mmol/L), cresolphtalein $(0.62$ $\mathrm{mmol} / \mathrm{L})$, and hydroxy-8 quinoleine (69 $\mathrm{mmol} / \mathrm{L})$. Incubation was carried out at room temperature for 5 min assuming the complex was stable for 1 hour.

\section{Statistical analysis}

Data were analyzed by unpaired Student's t-tests or 1way analysis of variance (ANOVA) and expressed as means \pm standard error of the means (SEM). All statistical tests were 2-tailed, and $\mathrm{p}<0.05$ was considered significant.

\section{Results}

We determined plasma creatinine and urea used as indexes of kidney injury (Figure 1). Garlic significantly increased plasma creatinine by $60 \%$ (Figure 1A) and urea by $20 \%$ (Figure 1B). Co-treatment with GSSE counteracted all garlic-induced disturbances to near control level. Thus GSSE decreased plasma creatinine by $36 \%$ and urea by $14 \%$.

Figure 2 showed that high garlic dose increased kidney MDA (Figure 2A) by 35\% and carbonylated proteins (Figure 2B) by $52 \%$. GSSE per se decreased renal MDA by $77 \%$ but had no effect on carbonylated proteins. GSSE also counteracted garlic-induced kidney lipoperoxidation by $57 \%$ and carbonylated proteins by $32 \%$.

We reported in Figure 3 the effects of garlic and GSSE 

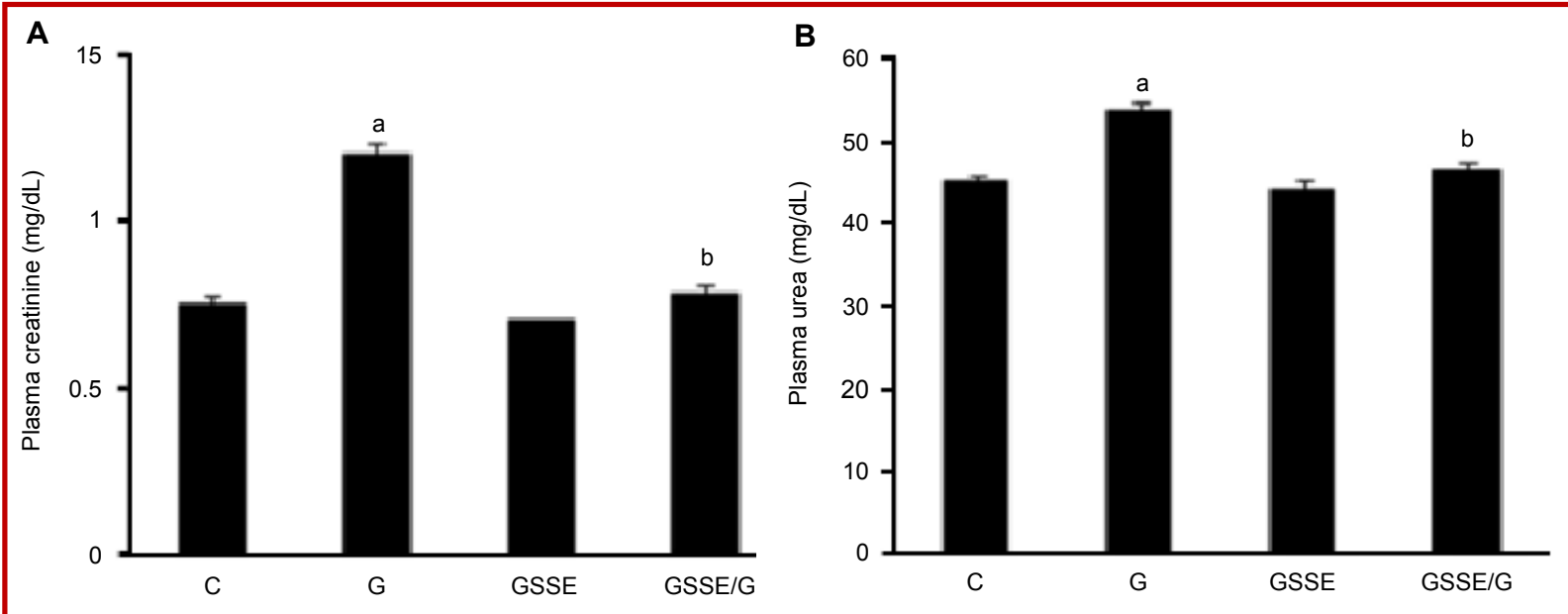

Figure 1: Effect of garlic and GSSE on plasma creatinine and urea. 10\% ethanol (C), garlic (G), grape seed and skin extract (GSSE) or garlic plus GSSE (GSSE/G) were administered to rats for 1 month and plasma cratinine (A), and urea (B) were determined. Results are expressed by mean \pm SEM $(n=10)$. ap $<0.01$ vs $C$. bp $<0.01$ vs $G$
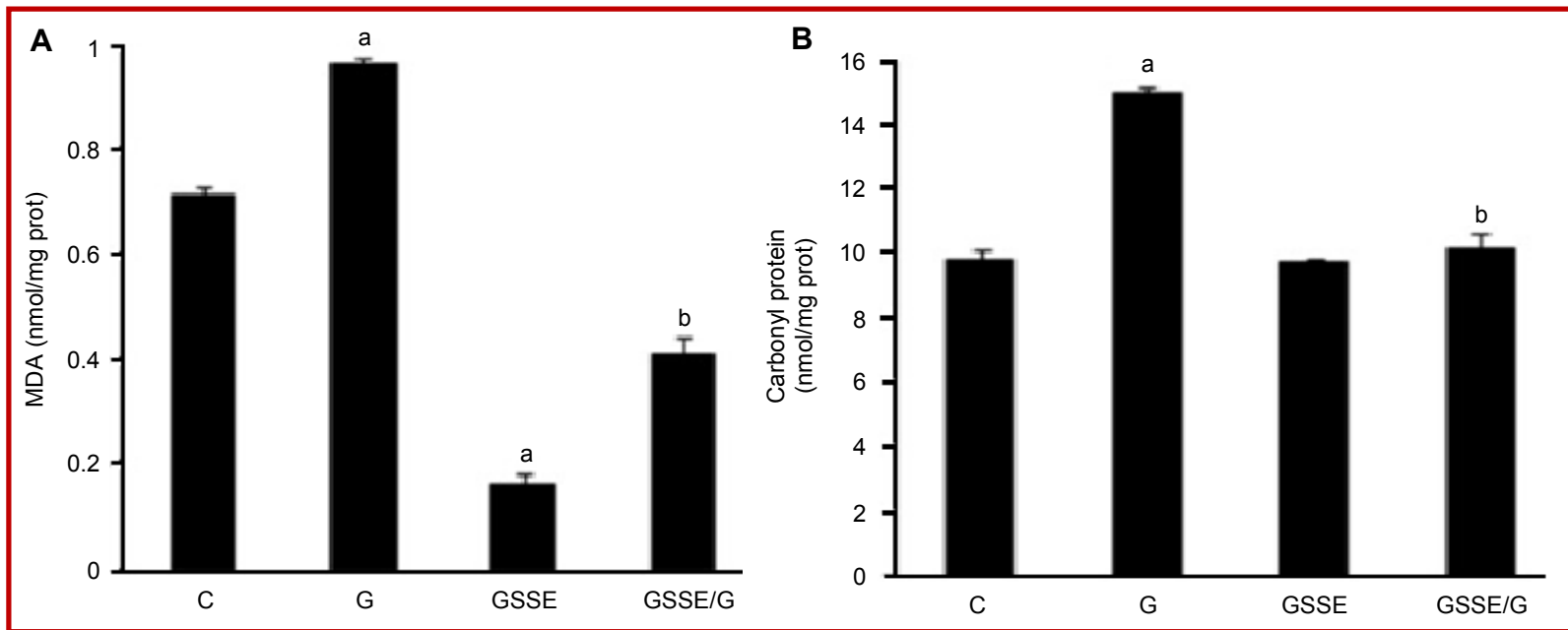

Figure 2: Effect of garlic and GSSE on renal lipoperoxidation and carbonylation. 10\% ethanol (C), garlic (G), grape seed and skin extract (GSSE) or garlic plus GSSE (GSSE/G) were administered to rats for 1 month and renal lipoperoxidation (A) and carbonylation (B) were determined. Results are expressed by mean \pm SEM $(n=10)$. ${ }^{a} p<0.01$ vs $C$. ${ }^{b} p<0.01$ vs $G$

on kidney anti-oxidant enzyme activities. Garlic unexpectedly increased CAT by 55\% (Figure 3A) but decreased POD (61\%) (Figure 3B) and SOD (21\%) (Figure 3C). In this latter case, garlic mainly decreased the $\mathrm{Mn}$ isoform (-70\%). GSSE per se clearly increased CAT $(+73 \%)$ and SOD (+ $26 \%)$ activities but decreased POD (- 45\%). Co-treatment with GSSE increased CAT, POD and SOD. In this latter case, GSSE co-treatment increased the Mn isoform.

We further sought to determine the putative involvement of renal mediators in garlic and GSSE mode of action (Figure 4). Garlic decreased renal free iron by $55 \%$ (Figure $4 \mathrm{~A}$ ), and increased $\mathrm{H}_{2} \mathrm{O}_{2}$ by $20 \%$ (Figure $4 \mathrm{~B}$ ) and calcium by $65 \%$ (Figure $4 \mathrm{C}$ ). Co- treatment with GSSE abrogated the garlic-induced disturbances of all three mediators to near control level.

\section{Discussion}

The present study revealed that high garlic dose administered ip to rats for 1 month induced renal injury. This effect is evidenced by increased lipoperoxidation and carbonylation and depletion of anti-oxidant enzyme activities such as POD and SOD. Kidney toxicity was also reflected by elevated plasma creatinine and urea, high level in renal $\mathrm{H}_{2} \mathrm{O}_{2}$ and calcium and a concomitant decrease in free iron. Paradoxically a positive effect of garlic on CAT activity might represent a "pro-oxidative state" in light of the unexpected prooxidant effect of CAT (Heck et al., 2003). In addition post-translational modifications of anti-oxidant enzymes and the subsequent gain in activity could also be involved (Borchi et al., 2010; Csar et al., 2001). Organosulfurs, flavonoids and phenolics are the major 


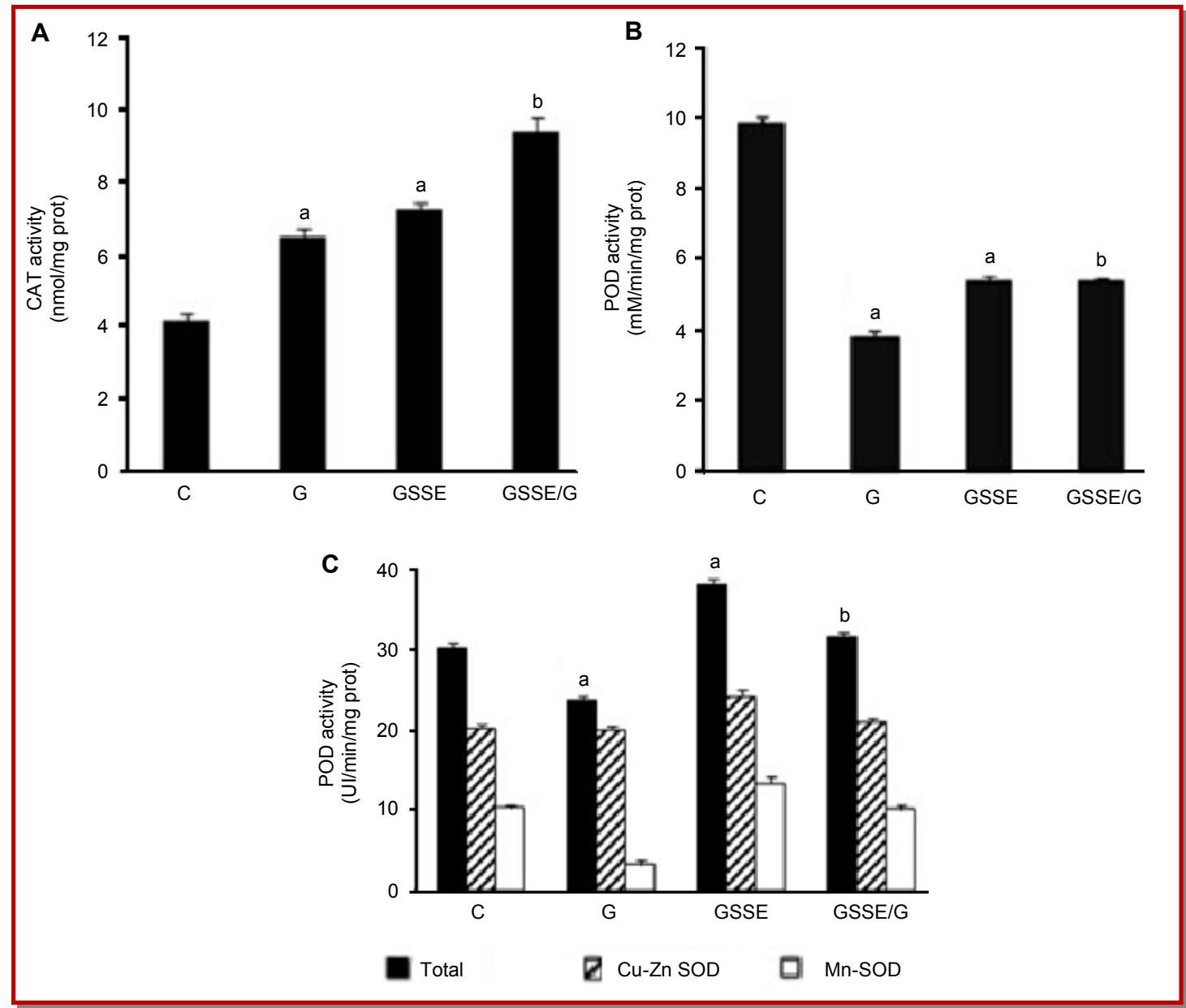

Figure 3: Effect of garlic and GSSE on kidney anti-oxidant enzyme activities. Rats were daily administered with $10 \%$ ethanol (C), garlic (G), grape seed and skin extract (GSSE) or garlic plus GSSE (GSSE/G) for 1 month and kidney catalase (A), peroxidase (B) and superoxide dismutase (C) activities were determined. Results are expressed by mean \pm SEM ( $n=10)$. ${ }^{a} p<0.01 \mathrm{vs} C$. ${ }^{b} p<0.01$ vs $G$

bioactive compounds of aqueous garlic extract (Shirzad et al., 2011). The effect of garlic extract on the kidney could likely result from synergism or antagonism between the various bioactive components of the mixture.

It is well established that elevated intracellular MDA and carbonyl proteins affected the fluidity of the membrane lipid bilayer (Bryszewska et al., 1995). This increase is correlated to pathological or stress conditions including aging (Rizvi and Maurya, 2007). Because of the high polyunsaturated fatty acid content of their membrane, renal cells are highly susceptible to oxidative damage. A possible mechanism by which garlic exerts renal toxicity is its ability to increase calcium and $\mathrm{H}_{2} \mathrm{O}_{2}$ which in turn decreases free iron. However, calcium has been previously shown to increase iron transport across the hepatocyte plasma membrane by a mechanism dependant on membrane fluidity (Nilsen, 1991). As in our present case, calcium and $\mathrm{H}_{2} \mathrm{O}_{2}$ acted as negative regulators of renal free iron and although the role of calcium channels in free iron uptake by the kidney remains unclear, one can speculate about differential calcium regulation by $\mathrm{H}_{2} \mathrm{O}_{2}$ or other ROS via either L-type or T-type calcium channels (Tabet et al., 2004).

Iron is known to play a central role in many pathologies as neurodegenerative (Castellani et al., 2007) and hepatocellular injury (Uchiyama et al., 2008). We observed an increase in plasma free iron (HamlaouiGasmi et al., 2011b) that could result from its extrusion from the kidney. Noteworthy that such an increase in plasma free iron has been attributed to DADS which induced the degradation of the ferritin light chain (Antosiewiecz et al., 2006). SAC, which behaved as a metal chelator, interacted with iron to prevent its redox cycling and by this way alleviated lipid peroxidation (Dairam et al., 2008). Furthermore both iron deficiency and iron excess can lead to cellular dysfunction, maintaining iron homeostasis is crucial (Andrews, 1999). Free iron is a well established catalyst 


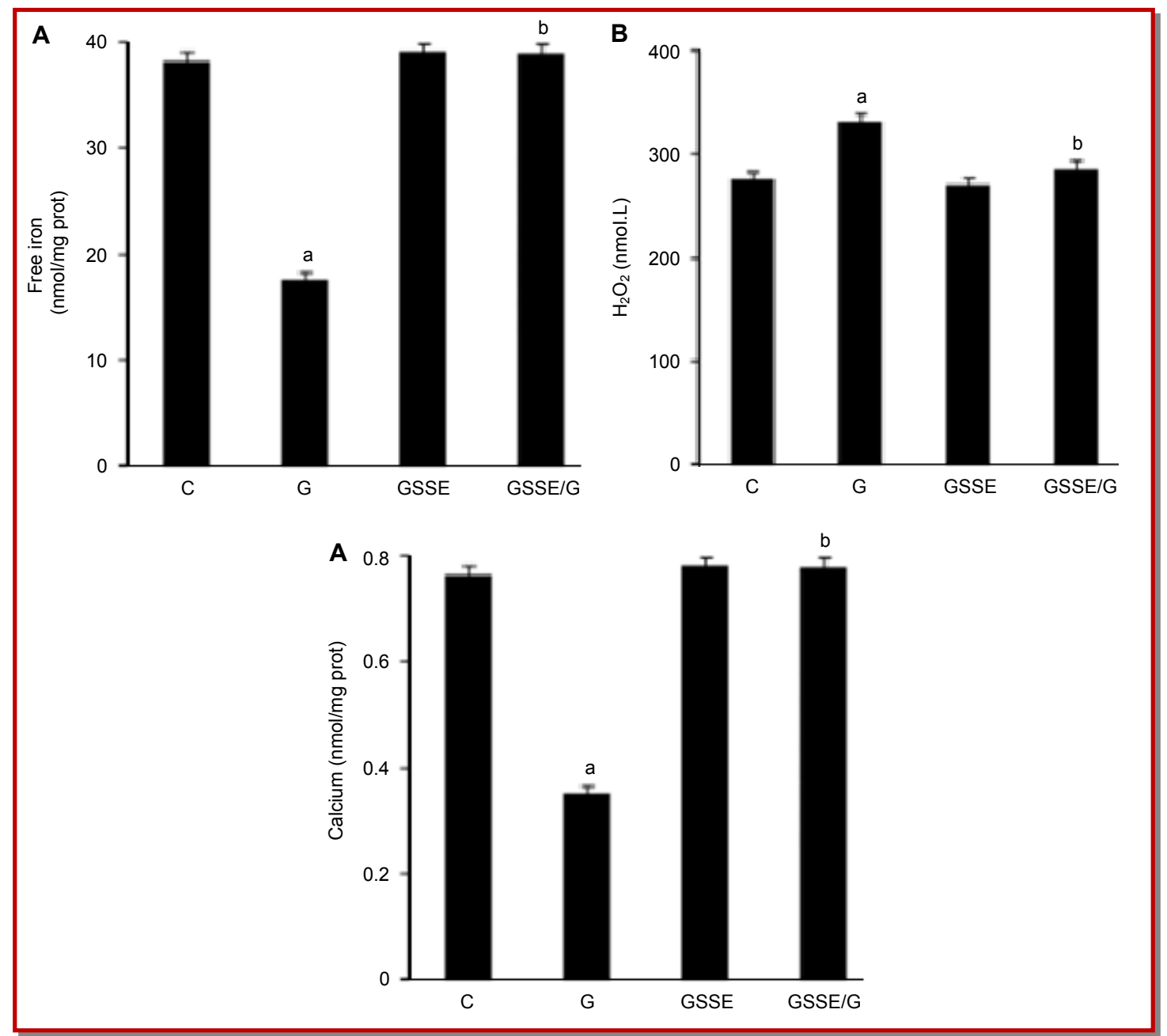

Figure 4: Effect of GSSE on garlic-induced intracellular mediators. Rats were daily administered with $10 \%$ ethanol (C), garlic (G), grape seed and skin extract (GSSE) or garlic plus GSSE (GSSE/G) for 1 month and renal free iron (A), $\mathrm{H}_{2} \mathrm{O}_{2}$ (B) and calcium (C) levels were determined. Results are expressed as means \pm SEM $(n=10)$. $a p<0.01$ vs C. ${ }^{b} p<0.01$ vs $G$

of auto-oxidation. Iron-mediated oxidations of cysteine residues represent a common mechanism through which $\mathrm{H}_{2} \mathrm{O}_{2}$ exerts its second messenger role in signal transduction pathways (Barbouti et al., 2007).

Furthermore, $\mathrm{H}_{2} \mathrm{O}_{2}$ is able to release intracellular calcium by a sulfhydryl sensitive way (Castro et al., 2004). One can thus speculate about $\mathrm{H}_{2} \mathrm{O}_{2}$ induced oxidation of sulfhydryl residues in proteins as calcium channels or anti-oxidant enzymes as CAT, this oxidation leading to some loss of function of the proteins as observed in the present study (Yamakura and Kawasaki, 2009).

To our knowledge our report is the first one to show that GSSE is renal-protective against garlic-induced oxidative stress and kidney dysfunction. GSSE was used at a dosage (500 mg/ $\mathrm{kg}$ bw) that was safe and near the optimal concentration precognized by Hebbar et al. (2005). GSSE was also tested at wide ranging doses reaching $4 \mathrm{~g} / \mathrm{kg} \mathrm{bw}$ with no sign of toxicity even at the histological level (not shown). GSSE has been previously shown to protect multiple target organs from doxorubicin (Hamlaoui et al., 2012a; Mokni et al., 2012) or garlic-induced toxicity owing to its anti-oxidant properties (Hamlaoui-Gasmi et al., 2012b).

Importantly, the most relevant effect of GSSE is its powerful ability in precluding garlic-induced increase in calcium and $\mathrm{H}_{2} \mathrm{O}_{2}$ which altered renal free iron. Grape seed and skin proanthocyanidins have been previously shown to protect multiple target organs from drug and chemical-induced toxicity, owing to their anti-oxidant and antiapoptotic properties (Bagchi et al., 2002). GSSE could act on calcium channels that have been implicated in the co-transport of calcium and iron in the myocardium and liver (Oudit et al., 2003). GSSE could also affect iron shuttling proteins as hepcidin and lipocalin 2, implicated in the regulation of calcium entry via L-type calcium current ( $\mathrm{Xu}$ et al., 2011) or as protective factor against $\mathrm{H}_{2} \mathrm{O}_{2}$ toxicity and 
apoptosis (Roudkenar et al., 2008). Further experiments using calcium channel blockers as verapamil or nifedipine should address the role of GSSE as a modulator of calcium channel activity or protein expression in iron and calcium co-transport (Otto-Duessel et al., 2011).

We do not yet know which active compounds present in the GSSE extract are responsible for the observed kidney protection. In fact GSSE composition is complex (Khanal et al., 2009) and a synergism could occur between skin-containing polyphenols and seeds containing fatty acids. In this respect, it was recently demonstrated that fatty acids from magnolias seeds were able to inhibit doxorubicin-induced increase in intracellular calcium, ROS generation and apoptosis in rat cardiomyocytes (Park et al., 2008).

Importantly, GSSE counteracted garlic-induced effects on $\mathrm{H}_{2} \mathrm{O}_{2}$, calcium and free iron. These effects could be mediated by ROS scavenging activity of GSSE as demonstrated for resveratrol (Leonard et al., 2003) or as shown for human erythrocytes (Pandey and Rizvi, 2009) and could result from the synergism between various grape-containing polyphenols (Liu, 2004). Consumption of GSSE is protective against cardiovascular diseases in humans (Das and Maulik, 2006) and the combination of resveratrol with quercetin synergistically inhibited the oxidative injury of human erythrocytes in vitro (Mikstacka et al., 2010). Resveratrol up-regulated anti-oxidant enzyme activities in rat brain (Mokni et al., 2007a), heart (Mokni et al., 2007b) and kidney (Chander et al., 2005). Resveratrol also efficiently protected against endotoxemia-induced acute phase response in rats (Sebai et al., 2009), protected the liver and the heart from oxidative stress induced by LPS (Sebai et al., 2010; Sebai et al., 2011), or acetaminophen (Sener et al., 2006), cadmium (Eybl et al., 2006), alcohol (Bujanda et al., 2006), CCl4 (Rivera et al., 2008), naphthalene (Sehirli et al., 2008), pyrogallol (Upadhyay et al., 2008) and ischemia/reperfusion injury (HassanKhabbar et al., 2008). In addition resveratrol has been shown to alleviate alcoholic fatty liver in mice (Ajmo et al., 2008) and more recently to exert protective effects on calcium-induced oxidative stress in rat heart mitochondria (Gutiérrez-Pérez et al., 2011). Quercetin, another polyphenol abundant in GSSE attenuated renal dysfunction and oxidative stress in rats (Muragundla and Kanwaljit, 2004). This polyphenol also reduces cisplatin toxicity in cultured tubular epithelial cells by scavenging free oxygen radicals (Kuhlmann et al., 1998). Quercetin, due to its anti-oxidant properties, prevented cyclosporine-induced ROS in kidney and consequently cyclosporine nephrotoxicity (Satyanarayana et al., 2001). Catechin reduces the renal ischemia/ reperfusion injury by boosting the anti-oxidant capacity and free radical scavenging activity. Moreover, catechin attenuates the increase in free iron after ischemia/ reperfusion and consequently decreases the hydroxyl radical formation through Haber-Weiss and Fenton reactions (Devinder et al., 2005).

One possible mechanism by which GSSE exerts its beneficial effect on kidney is its ability to chelate free iron and scavenge $\mathrm{H}_{2} \mathrm{O}_{2}$ as recently demonstrated by Charradi et al. (2011). Further studies should analyze the implication of specific proteins involved in free iron metabolism as hepcidin (Isoda et al., 2009). Moreover, $\mathrm{H}_{2} \mathrm{O}_{2}$ is able to induce dual roles in both survival and cell death pathways, largely depending on its concentration and also on the cell type. However, our results also raised several discrepancies. In particular garlic appeared in the same time as pro-oxidant, increasing MDA, carbonyl proteins, calcium and $\mathrm{H}_{2} \mathrm{O}_{2}$ and also anti-oxidant by increasing CAT activity. GSSE increased CAT and SOD activities mainly the Mn isoform but unexpectedly decreased POD. Our data are reminiscent of those described by Borchi et al. (2010) who showed in a human heart failure model, increased CAT and GPx activities due solely to increased tyrosine phosphorylation. In our case, high garlic dose could provoke phosphorylation of CAT activity but not GSSE which even counteracted garlic effect on post- translational modification of CAT. Garlic-induced oxidative stress was also associated with impaired renal function leading to a marked increase in plasma creatinine and urea. In addition we can't exclude an effect of garlic as well as of GSSE on transition metals as Mn accumulation into renal cells. As garlic induced in the same time calcium accumulation and an increase in Mn-SOD activity it would be interesting to correlate the observed increase in Mn-SOD with a hypothetical accumulation of $\mathrm{Mn}$ into renal cells.

\section{Conclusion}

High garlic dose is pro-oxidative and induced kidney toxicity as assessed by free iron depletion and GSSE is renal-protective partly by its anti-oxidant action.

\section{References}

Aebi H. Catalase in vitro. Methods Enzymol. 1984; 105: 121-26.

Ajmo J, Liang X, Rogers C, Pennock B, You M. Resveratrol alleviates alcoholic fatty liver in mice. Am J Physiol. Gastrointest Liver Physiol. 2008; 295: 833-42.

Andrews NC. Disorders of iron metabolism. N Engl J Med. 1999; 341: 1986-95.

Antosiewicz J, Herman-Antosiewicz A, Marynowski S, Singh S. C-Jun $\mathrm{NH}_{2}$-terminal kinase signaling axis regulates diallyl trisulfide-induced generation of reactive oxygen species and cell cycle arrest in human prostate cancer cells. Cancer Res. 2006; 66: 5379-86.

Bagchi D, Sen CK, Ray SD, Das DK, Bagchi M, Preuss HG, 
Vinson JA. Molecular mechanisms of cardioprotection by a novel grape seed proanthocyanidin extract. Mutat Res. 2003; 523: 87-97.

Barbouti A, Amorgianiotis C, Kolettas E, Kanavaros P, Galaris D. Hydrogen peroxide inhibits caspase-dependent apoptosis by inactivating procaspase- 9 in an iron-dependent manner. Free Rad Biol Med. 2007; 43: 1377-87.

Berginc K, Milisav I, Kristl A. Garlic flavonoids and organosulfur compounds: Impact on the hepatic pharmacokinetics of saquinavir and darunavir. Drug Metab Pharmacokinet. 2010; 25: 521-30.

Borchi E, Bargelli V, Stillitano F, Giordano C, Sebastiani M, Nassi PA, d'Amati G, Cerbai E, Nediani C. Enhanced ROS production By NADPH oxidase is correlated to changes in anti-oxidant enzyme activity in human heart failure. Biochim Biophys Acta. 2010; 1802: 331-38.

Bryszewska M, Zavodnik IB, Niekurzak A, Szosland K. Oxidative processes in red blood cells from normal and diabetic individuals. Biochem Mol Biol Int. 1995; 37: 345-54.

Bujanda L, Garcýa-Barcina M, Gutierrez-de Juan V, Bidaurrazaga J, De Luco MF, Gutierrez-Stampa M, Larzabal M, Hijona E, Sarasqueta C, Echenique-Elizondo M, Arenas JI. Effect of resveratrol on alcohol-induced mortality and liver lesions in mice. BMC Gastroenterol. 2006; 6: 35.

Castellani RJ, Moreira PI, Liu G, Dobson J, Perry G, Smith MA, Zhu X. Iron: The redox-active center of oxidative stress in Alzheimer disease. Neurochem Res. 2007; 32: 1640-45.

Castro J, Bittner CX, Humeres A, Montecinos VP, Vera JC, Barros LF. A cytosolic source of calcium unveiled by hydrogen peroxide with relevance for epithelial cell death. Cell Death Differ. 2004; 11: 468-78.

Chance B, Maehly AC. Assay of catalases and peroxidases. Methods Enzymol. 1955; 2: 764-817.

Chander V, Tirkey N, Chopra K. Resveratrol, a polyphenolic phytoalexin protects against cyclosporine-induced nephrotoxicity through nitric oxide dependent mechanism. Toxicol. 2005; 210: 55-64.

Charradi K, Sebai H, Elkahoui S, Ben Hassine F, Limam F, Aouani E. Grape seed extract alleviates high-fat dietinduced obesity and heart dysfunction by preventing cardiac siderosis. Cardiovasc Toxicol. 2011; 11:28-37.

Chatelain K, Phippen S, Mc Cabe J, Teeters CA, O'Malley S, Kingsley K. Cranberry and grape seed extracts inhibit the proliferative phenotype of oral squamous cell carcinomas. Evid Based Complement Altern Med. 2011; 2011.

Csar XF, Wilson NJ, Strike P, Sparrow L, McMahon KA, Ward AC, Hamilton JA. Copper/zinc superoxide dismutase is phosphorylated and modulated specifically by granulocytecolony stimulating factor in myeloid cells. Proteomics 2001; 1: $435-43$

Dairam A, Fogel R, Daya S, Limson JL. Anti-oxidant and ironbinding properties of curcumin, capsaicin, and S- allylcysteine reduce oxidative stress in rat brain homogenate. J Agric Food Chem. 2008; 56: 3350-56.

Das DK, Maulik N. Resveratrol in cardioprotection: a therapeutic promise of alternative medicine. Mol Interv. 2006; 6:
$36-47$.

Decordé K, Teissedre PL, Sutra T, Ventura E, Cristol JP, Rouanet JM. Chardonnay grape seed procyanidin extract supplementation prevents high-fat diet-induced obesity in hamsters by improving adipokine imbalance and oxidative stress markers. Mol Nutr Food Res. 2009; 53: 659-66.

Devinder S, Vikas C, Kanwaljit C. Protective effect of catechin on ischemia-reperfusion-induced renal injury in rats. Pharmacoligical Reports. 2005; 57: 70-76

Dewanto V, Wu X, Adom KK, Liu RH. Thermal processing enhances the nutritional value of tomatoes by increasing total anti-oxidant activity. J Agric Food Chem. 2002; 50: 301014.

Draper HH, Hadley M. Malondialdehyde determination as index of lipid peroxidation. Methods Enzymol. 1990; 186: 421 -31 .

Eybl V, Kotyzova D, Koutensky J. Comparative study of natural anti-oxidants-curcumin, resveratrol and melatonin in cadmium-induced oxidative damage in mice. Toxicology 2006; 225: $150-56$

Gutiérrez-Pérez A, Cortés-Rojo C, Noriega-Cisneros R, Calderón-Cortés E, Manzo-Avalos S, Clemente-Guerrero M, Godínez-Hernández D, Boldogh I, Saavedra-Molina A. Protective effects of resveratrol on calcium-induced oxidative stress in rat heart mitochondria. J Bioenerg Biomembr. 2011; 43: 101-07.

Hamlaoui S, Mokni M, Limam N, Carrier A, Limam F, Amri M, Marzouki L, Aouani E. Grape seed and skin extract protects against acute chemotherapy toxicity induced by doxorubicin in rat red blood cells and plasma. Bangladesh J Pharmacol. 2012a; 7: 54-62

Hamlaoui-Gasmi S, Mokni M, Limam N, N'guessan P, Carrier A, Limam F, Amri M, Aouani E, Marzouki L. Grape seed and skin extract mitigates garlic-induced oxidative stress in rat liver. Can J Physiol Pharmacol. 2012b; 90:547-56.

Hamlaoui-Gasmi S, Mokni M, Limam N, Limam F, Aouani E, Amri M, Marzouki L. Grape seed extract mitigates garlicinduced oxidative stress in rat spleen and plasma. J Med Plants Res. 2011b; 5: 6076-84.

Hamlaoui-Gasmi S, Mokni M, Aouani E, Amri M, Marzouki L. Modulation of hematological parameters by garlic based on route of administration in rat. J Food Biochem. 2011a; 35: 442 -53 .

Hassan-Khabbar S, Cottart CH, Wendum D, Vibert F, Clot JP, Savouret JF, Conti M, Nivet-Antoine V. Postischemic treatment by trans-resveratrol in rat liver ischemiareperfusion: A possible strategy in liver surgery. Liver Transplant. 2008; 14: 451-59.

Hebbar V, Shen G, Hu R, Kim BR, Chen C, Korytko PJ, Crowell JA, Levine BS, Kong AN. Toxicogenomics of resveratrol in rat liver. Life Sci. 2005; 76: 2299-2314.

Heck DE, Vetrano AM, Mariano TM, Laskin JD. UVB light stimulates production of reactive oxygen species. Unexpected role of catalase. J Biol Chem. 2003; 278: 2243-46.

Isoda $\mathrm{M}$, Hanawa $\mathrm{H}$, Watanabe $\mathrm{R}$, Yoshida $\mathrm{T}$, Toba $\mathrm{K}$, Yoshida K, Kojida M, Otaki K, Hao K, Ding L, Tanaka K, 
Takayama T, Kato K, Okura Y, Kodama M, Ota Y, Hayashi J, Aizawa Y. Expression of the peptide hormone hepcidin increases in cardiomyocytes under myocarditis and myocardial infarction. J Nutr Biochem. 2009; 21:749-56.

Jiménez-Aliaga K, Bermejo-Bescós P, Benedí J, Martín-Aragón S. Quercetin and rutin exhibit antiamyloidogenic and fibrildisaggregating effects in vitro and potent anti-oxidant activity in APPswe cells. Life Sci. 2011; 89: 939-45.

Kakinuma K, Yamaguchi T, Kaneda M, Shimada K, Tomita $\mathrm{Y}$, Chance B. A determination of $\mathrm{H}_{2} \mathrm{O}_{2}$ release by the treatment of human blood polymorphonuclear leukocytes with myristate. J Biochem. 1979; 86: 87-95.

Kelen M, Tepe B. Screening of anti-oxidative properties and total phenolic compounds of various extracts of three different seed of grape varieties (Vitis vinifera L.) from Turkish flora. Pakistan J Biol Sci. 2007; 10: 403-08.

Khanal RC, Howard LR, Prior RL. Procyanidin content of grape seed and pomace, and total anthocyanin content of grape pomace as affected by extrusion processing. J Food Sci. 2009; 74: H174-82.

Kowalczyk MC, Kowalczyk P, Tolstykh O, Hanausek M, Walaszek Z, Slaga TJ. Synergistic effects of combined phytochemicals and skin cancer prevention in SENCAR mice. Cancer Prev Res (Phila). 2010; 3: 170-78.

Kuhlmann MK, Horsch E, Burkhardt G, Wagner M, Köhler H. Reduction of cisplatin toxicity in cultured renal tubular cells by the bioflavonoid quercetin. Arch Toxicol. 1998; 72: 536-40.

Leardi A, Caraglia M, Selleri C, Pepe S, Pizzi C, Notaro R, Fabbrocini A, De Lorenzo S, Musicò M, Abbruzzese A, Bianco AR, Tagliaferri P. Desferioxamine increases iron depletion and apoptosis induced by ara-C of human myeloid leukaemic cells. Brit J Haematol. 1998; 102: 746-52.

Leonard SS, Xia C, Jiang BH, Stinefelt B, Klandorf H, Harris GK, Shi X. Resveratrol scavenges reactive oxygen species and effects radical-induced cellular responses. Biochem Bioph Res Co. 2003; 309: 1017-26.

Levine LR, Garland D, Oliver CN, Amici A, Climent I, Lenz AG, Ahn BW, Shaltiel S, Stadtman ER .Determination of carbonyl content in oxidatively modified proteins. Method Enzymol. 1990; 186: 464-78.

Liu RH. 2004. Potential synergy of phytochemicals in cancer prevention: Mechanism of action. J Nutr. 134(12S): 3479S$85 S$.

Mikstacka R, Rimando AM, Ignatowicz E. Anti-oxidant effect of transresveratrol, pterostilbene, quercetin and their combinations in human erythrocytes in vitro. Plant Foods Hum Nutr. 2010; 65: 57-63.

Misra HP, Fridovich I. The role of superoxide anion in autoxidation of epinephrine and a simple assay for SOD. J Biol Chem. 1972; 247: 3170-75.

Mokni M, Elkahoui S, Limam F, Amri M, Aouani E. Effect of resveratrol on anti-oxidant enzyme activities in the brain of healthy rat. Neurochem Res. 2007a; 32: 981-87.

Mokni M, Limam F, Elkahoui S, Amri M, Aouani E. Strong cardioprotective effect of resveratrol, a red wine polyphenol, on isolated rat hearts after ischemia/reperfusion injury.
Arch Biochem Biophys. 2007b; 457: 1-6.

Mokni M, Hamlaoui-Guesmi S, Amri M et al. Grape seed and skin extract protects against acute chemotherapy toxicityinduced by doxorubicin in rat heart. Cardiovasc Toxicol. 2012, 2012.

Muragundla A, Kanwaljit C. Quercetin, an anti-oxidant biflavonoid, attenuates diabetic nephropathy in rats. Clin Exp Pharmacol Physiol. 2004; 31: 244-48.

National Research Council. Guide for the care and the use of laboratory animals. National institute of health, Bethesda. 1985; 20: 85-123.

Ngamukote S, Mäkynen K, Thilawech T, Adisakwattana S. Cholesterol-lowering activity of the major polyphenols in grape seed. Molecules 2011; 16: 5054-61.

Nilsen T. Effects of calcium on hepatocyte iron uptake from transferrin, iron-pyrophosphate and iron-ascorbate. Biochim Biophys Acta. 1991; 1095: 39-45.

Ohnishi ST, Barr JK. A simple method of quantitating protein using the biuret and phenol reagent. Anal Biochem. 1978; 86: $193-200$

Otto-Duessel M, Brewer C, Wood JC. Interdependence of cardiac iron and calcium in a murine model of iron overload. Transl Res. 2011; 157: 92-99.

Oudit GY, Sun H, Trivieri MG, Koch SE, Dawood F, Ackerley C, Yazdanpanah M, Wilson GJ, Schwartz, A, Liu PP, Backx $\mathrm{PH}$. L-type $\mathrm{Ca}^{2+}$ channels provide a major pathway for iron entry into cardio myocytes in iron-overload cardiomyopathy. Nature Med. 2003; 9: 1187-94.

Pandey KB, Rizvi SI. Protective effect of resveratrol on formation of membrane protein carbonyls and lipid peroxidation in erythrocytes subjected to oxidative stress. Appl Physiol Nutr Metab. 2009; 34: 1093-97.

Park KH, Kim SY, Gul R, Kim BJ, Jang KY, Chung HT, Sohn $\mathrm{DH}$. Fatty acids ameliorate doxorubicin-induced intracellular calcium increase and apoptosis in rat cardiomyocytes. Biol Pharm Bull. 2008; 31: 809-15.

Renaud S, De Lorgeril M. Wine, alcohol, platelets, and the French paradox for coronary heart disease. Lancet 1992; 339: 1523-26.

Rivera H, Shibayama M, Tsutsumi V, Perez-Alvarez V, Muriel $\mathrm{P}$. Resveratrol and trimethylated resveratrol protect from acute liver damage induced by $\mathrm{CCl}_{4}$ in the rat. J Appl Toxicol. 2008 ; 28: 147-55.

Rizvi SI, Maurya PK. Markers of oxidative stress in erythrocytes during aging in humans. Ann NY Acad Sci. 2007; 1100: 373-82.

Roudkenar MH, Halabian R, Ghasemipour Z, Roushandeh AM, Rouhbakhsh M, Nekogoftar M, Kuwahara Y, Fukumoto M, Shokrgozar MA. Neutrophil gelatinase-associated lipocalin acts as a protective factor against $\mathrm{H}_{2} \mathrm{O}_{2}$ toxicity. Arch Med Res. 2008; 39: 560-66.

Satyanarayana PSV, Singh D, Chopra K. Quercetin, a bioflavonoid, protects against oxidative stress-related renal dysfunction by cyclosporine in rats. Methods Find Exp Clin Pharmacol. 2001; 23: 175. 
Sebai H, Ben-Attia M, Sani M, Aouani E, Ghanem-Boughanmi N. Protective effect of resveratrol in endotoxemia-induced acute phase response in rats. Arch. Toxicol. 2009; 83: 335-40.

Sebai H, Sani M, Aouani E, Ghanem-Boughanmi N. Cardioprotective effect of resveratrol on lipopolysaccharideinduced oxidative stress in rat. Drug Chem Toxicol. 2011; 34: 146-50.

Sebai H, Sani M, Ghanem-Boughanmi N, Aouani E. Prevention of lipopolysaccharide-induced mouse lethality by resveratrol. Food Chem Toxicol. 2010; 48: 1543-49.

Sehirli O, Ozel Y, Dulundu E, Topaloglu U, Ercan F, Sener G. Grape seed extract treatment reduces hepatic ischemiareperfusion injury in rats. Phytother Res. 2008; 22: 43-48.

Sener G, Toklu HZ, Sehirli AO, Velioðlu-Oðünç A, Cetinel S, Gedik N. Protective effects of resveratrol against acetaminophen-induced toxicity in mice. Hepatol Res. 2006; 35: 62-68.

Shirzad H, Taji F, Rafieian-Kopaei M. Correlation between anti -oxidant activity of garlic extracts and WEHI-164 fibrosarcoma tumor growth in BALB/c mice. J Med Food. 2011; 14: $969-74$

Singleton VL, Rossi JA. Colorimetry of total phenolic with phosphomolybdic-phosphotungstic acid reagent. Am J Enol Vitic. 1965; 16: 144-58.

Stern J, Lewis WH. The colorimetric estimation of calcium in serum with ocresolphthalein complexone. Clin Chim Acta. 1957; 2: 576-80.

Sun BS, Ricardo-Da-Silva JM, Spranger MI. Critical factors of vanillin assay for catechins and proanthocyanidins. J Agric Food Chem. 1998; 46: 4267-74.
Suwannaphet W, Meeprom A, Yibchok-Anun S, Adisakwattana S. Preventive effect of GSE against high fructose diet-induced insulin resistance and oxidative stress in rats. Food Chem Toxicol. 2010; 48: 1853-57.

Tabet F, Savoia C, Schiffrin EL, Touyz RM. Differential calcium regulation by hydrogen peroxide and superoxide in vascular smooth muscle cells from spontaneously hypertensive rats. J Cardiovasc Pharmacol. 2004; 44: 200-08.

Uchiyama A, Kim JS, Kon K, Jaeschke H, Ikejima K, Watanabe $\mathrm{S}$, Lemasters JJ. Translocation of iron from lysosomes into mitochondria is a key event during oxidative stress-induced hepatocellular injury. Hepatology 2008; 48: 1644-54.

Upadhyay G, Singh AK, Kumar A, Prakash O, Singh MP. Resveratrol modulates pyrogallol-induced changes in hepatic toxicity markers, xeno- biotic metabolizing enzymes and oxidative stress. Eur J Pharmacol. 2008; 596: 146-52.

Wang YJ, Thomas P, Zhong JH, Bi FF, Kosaraju S, Pollard A, Fenech M, Zhou XF. Consumption of grape seed extract prevents amylö̈d-â deposition and attenuates inflammation in brain of an Alzheimer's disease mouse. Neurotox Res. 2009; 15: 3-14.

Xu L, Lai D, Cheng J, Lim HJ, Keskanokwong T, Backs J, Olson EN, Wang Y. Alterations of L- type calcium current and cardiac function in CaMKII knockout mice. Circ Res. 2010; 107: 398-407.

Yamakura F, Kawasaki H. Post-translational modifications of superoxide dismutase. Biochim Biophys Acta. 2010; 1804: 318 -25 . 